\title{
Screening of phyto-sources from foothill of Himalayan mountain for livestock methane reduction
}

\author{
P. K. Malik ${ }^{1}$ (1) Y. Uyeno ${ }^{2} \cdot$ A. P. Kolte ${ }^{1} \cdot$ R. Kumar $^{3} \cdot$ S. Trivedi ${ }^{1} \cdot$ R. Bhatta $^{1}$ \\ (C) Springer Nature Switzerland AG 2019
}

\begin{abstract}
The present study was undertaken to explore the methane reduction potential of phyto-sources from the foothills of Himalayan region. The qualitative screening of phyto-sources confirmed the presence of tannins in $\sim 80 \%$ of the samples. Similarly, most of the phyto-samples were also possesses flavanoids (66\%) and terpenoids (94\%); however, none of the samples consist saponins or phlobatannins. The highest tannins concentration was reported in Terminalia chebula (245 g/kg DM), Zanthoxylum alatum ( $219 \mathrm{~g} / \mathrm{kg} \mathrm{DM)} \mathrm{and} \mathrm{Punica} \mathrm{granatum} \mathrm{(207} \mathrm{g/kg} \mathrm{DM).} \mathrm{Phyto-sources} \mathrm{such}$ as Pittosporum eriocarpum, Prunusdomestica and Berberis lycium contain condensed and hydrolysable tannins in nearly equal proportions and comparatively produce lesser methane than non-tanniniferous phyto-sources sources or phytosources which possess either condensed or hydrolysable tannins. The study established that entodinomorphs were most vulnerable protozoa to tanniniferous phyto-sources. The attenuation of tannins impact through polyethylene glycol (PEG-6000) addition revealed a substantial increase in total volatile fatty acids (up to 23\%) and ammonia nitrogen (up to 50\%). It can be inferred from the study that Prunus domestica, Berberis lycium and Terminalia chebula due to their methane mitigation potential can be incorporated in animal feed for reducing methane emission. The present study unequivocally demonstrated that tannins-containing phyto-sources could be of great interest in the development of novel anti-methanogenic feed additives. However, the optimization of level of inclusion for the selected phyto-sources in animals diet should be studied.
\end{abstract}

Keywords Methane mitigation · Plant secondary metabolites $\cdot$ Phyto-sources $\cdot$ Rumen $\cdot$ Tannins

\section{Introduction}

Due to the ever-increasing methane emission, a massive hunt has been hurled to reduce emission from the ruminants. Globally, the livestock sector contributes $18 \%$ percent of the total greenhouse gas emissions [1]. Enteric fermentation alone is accounted for $15-20 \%$ of the global methane emission. Ruminant is one of the largest sources of methane emission and globally produce 81-92 million metric tons methane per year [1]. Methane has 25 times more heat trapping potential than $\mathrm{CO}_{2}$ and one of the main factors responsible for global warming. In addition, enteric methane emission also represents a substantial loss of $8-15 \%$ of the total energy intake [2]. Due to high calorific value $(39.5 \mathrm{~kJ} / \mathrm{l})$ of methane, its emission therefore deprives the animals from a substantial fraction of energy that otherwise would have been utilized for different productive functions. In developing countries, the increasing demand for animal products would result in large methane emission. Therefore, disproportionate productivity

\section{Electronic supplementary material The online version of this article (https://doi.org/10.1007/s42452-019-0229-6) contains} supplementary material, which is available to authorized users.

P. K. Malik, malikndri@gmail.com | ${ }^{1}$ Energy Metabolism Laboratory, ICAR-National Institute of Animal Nutrition and Physiology, Bangalore 560 030, India. ${ }^{2}$ Shinshu University, Ina, Nagano, Japan. ${ }^{3} \mathrm{G}$. B. Pant, University of Agriculture and Technology, Pantnagar 263145 , India. 
intensification would certainly lead to the larger methane emission, if suitable and sustainable methane ameliorative measures are not developed and adopt. Thus, amelioration of methane emission from livestock will not only protect the environment, but also lead to productivity enhancement with better energy utilization efficiency.

Feed additives such as ionophores proved very effective in reducing energy and protein losses [3]; however, contemporary biosecurity threats have restricted their usage in the diet in many European countries (EU directive 1831/2003/Cee). Researchers are continuously trying to develop the effective alternates for ionophores that can modulate the rumen fermentation and reduce methane emission. Use of plant secondary metabolites, as rumen modifiers appear an attractive alternative. These are active biomolecules and being considered environment friendly if used at the appropriate level. Tannin is one of the largely studied plant secondary metabolites that lead to direct and indirect inhibition of the rumen methanogenesis; however, the extent of methane reduction is purely dependent on tannins concentration and chemical composition. Plant secondary metabolites-containing phyto-sources are not uniform and abruptly distributed among the countries/region and confine to region specific. Thus, phyto-sources hold potential methane reduction properties will have no meaning, if inadequately available where intervention(s) for methane reduction is required. The constraint of patchy availability forces the researchers for a continuous search of plant secondary metabolitescontaining phyto-sources that lead to methane reduction.

The Himalayan region is a hotspot of plant diversity possessing more than 10,000 plant species; however, these phyto-sources have not yet been explored for the methane reduction. These unexplored phyto-sources need to be screened for the presence of plant secondary metabolites (PSM), their anti-methanogenic potential and modalities for their inclusion in the animal diet.

\section{Materials and methods}

\subsection{Sample collection}

Total 15 plant leaves samples were collected from the foothill of Himalayan region ( $\left.27^{\circ} 59^{\prime} 17^{\prime \prime} \mathrm{N} 86^{\circ} 55^{\prime} 31^{\prime \prime} \mathrm{E}\right)$ spread in Nanital, Uttarakhand, India at a height of 8848 meters above the sea level. The samples were collected from August to October 2015 during post- monsoon season. Approximately, $500 \mathrm{~g}$ sample was harvested from the five trees, air dried for about 10-15 days and pooled. The samples were brought to the laboratory and again air dried for 7-10 days in a well-ventilated shed. The air-dried samples were ground to pass $1 \mathrm{~mm}$ sieve and stored in airtight container in a dry, cool and dark place till further analysis.

\subsection{Screening for the presence of plant secondary metabolites}

The air-dried ground leaf samples were screened for the presence of tannins, saponins, flavonoids, alkaloids, terpenoids, glycosides and phlobatannins. For the identification of PSM, qualitative tests were carried following the standard protocols described by [4]. However, the presence of alkaloids in the samples was confirmed following the methodology of [5].

For the quantitative tannin assay, ground samples $(0.2 \mathrm{~g})$ were extracted twice in $10 \mathrm{~mL}$ aqueous acetone (acetone/water, 7:3) for $20 \mathrm{~min}$ in an ultrasonic water bath. The extracted samples were then centrifuged at $6000 \mathrm{~g}$ for $10 \mathrm{~min}$ at $4{ }^{\circ} \mathrm{C}$ and the supernatant were combined using for tannin analysis. Total phenols (TP), total tannin (TT) and condensed tannin (CT) in the samples were determined following the previously described procedure ([6]. All the determinations were carried out in duplicate.

\subsection{Chemical composition}

The proximate analysis of dried leave samples was performed for the following principles using AOAC (1990): crude protein (method 984.13), ether extract and ash (method 942.05). The aNDFom corrected for neutral detergent fiber (NDF)-ash was determined following the standard procedure [7] using heat stable a-amylase (Sigma Aldirch A3306) at $1 \mathrm{~mL}$ per $100 \mathrm{~mL}$ of NDF solution. Feed samples were also analyzed for acid detergent fibre (ADF) and acid detergent lignin (ADL) following the previously described procedure [7]. All the analysis were carried out in triplicate and presented as $\mathrm{g} / \mathrm{kg}$ DM.

\subsection{In vitro gas production}

In vitro experiments were conducted in a series at the Energy Metabolism Laboratory of National Institute of Animal nutrition and physiology, Bangalore, India. For collecting the rumen liquor from animals, an approval was obtained from the Institute Animal Ethics Committee (IAEC) and followed the standard guidelines.

The rumen liquor was collected prior to the morning feeding from two cannulated Holstein-Friesian crossbred bulls fed ad libitum on a total mixed ration consisting finger millet (Elusine coracana) straw and concentrate mixture in 60:40. The rumen liquor was strained through four layers of muslin cloth, pooled and used as a source of inoculum for in vitro incubation. Approximately, $30 \mathrm{~mL}$ of buffered rumen inoculum ([8] was dispensed in $100 \mathrm{~mL}$ calibrated 
glass syringe (Haeberle, Germany) containing $0.2 \mathrm{~g}$ air equilibrated sample. All the incubations were carried out in triplicate at $39^{\circ} \mathrm{C}$ for $24 \mathrm{~h}$ and each sample was incubated two times with an interval of 1 week. To quantify gas production derived from the culture medium and rumen inoculum, two blanks (without leaf sample) were included in every set. Every time standard hay (University of Hohenheim, Stuttgart, Germany) sample was used as a reference. In the subsequent experiment, tannin interference on fermentation was assessed using polyethylene glycol (PEG6000 ). All the incubations were carried out in triplicate at $39^{\circ} \mathrm{C}$ for $24 \mathrm{~h}$ and each sample was incubated two times with an interval of 1 week. The magnitude of increase in gas production due to the addition of PEG to the tanniferous leaves at a ratio of 2:1 was taken as an index of tannin's interference on rumen fermentation [9].

After $24 \mathrm{~h}$ of incubation, so as experiment 1 and 2 , total gas produced was estimated by the displacement of the syringe piston. Net gas produced from the fermentation of substrate was calculated by subtracting the blank values from the test samples. The gas produced in standard syringe was used to check day-to-day variation in the quality of inoculum. For estimating methane, $1.0 \mathrm{~mL}$ of gas was sampled with an airtight syringe (Hamilton Company, Reno, NV, USA) from the headspace of syringe (having one outlet) using a specialized adapter fitted to the silicon tubing. The samples were injected manually into ThermoFisher gas chromatograph equipped with thermal conductivity detector and stainless steel column packed with Porapak-Q. The injector oven, column oven and detector temperatures were maintained at $60^{\circ} \mathrm{C}, 100^{\circ} \mathrm{C}$ and $110^{\circ} \mathrm{C}$ respectively for analyzing methane in total gas. Based on the estimated methane percentage in gas, methane production in $\mathrm{mL}$ was calculated in each sample using the formula given below

Methane $(\mathrm{mL})=$ Methane $\%$ in the sample

$$
\times \text { total gas produced }(\mathrm{mL}) \text {. }
$$

After PEG addition, the \% increase in methane production was calculated as

Methane $(\mathrm{mL})=\frac{\mathrm{CH}_{4} \text { with PEG addition }-\mathrm{CH}_{4} \text { without } \mathrm{PEG} \text { addition }}{\mathrm{CH}_{4} \text { without } \mathrm{PEG} \text { addition }}$

\subsection{Fermentation characteristics and protozoal enumeration}

The rumen fluid samples were analyzed for ammonia- $\mathrm{N}$ (mg/dL) following the previously described procedure ([10]; whilst total volatile fatty acid (TVFA, mM) was estimated as per the described method ([11]. Supernatant fluid from each syringe was taken for the enumeration of protozoa. The rumen ciliates were identified as described previously [12]. Spirotrichs unidentified to generic level were classified into small spirotrichs (mainly entodinimorphs with an average size $42 \mu \mathrm{m} \times 23 \mu \mathrm{m}$ ) and large spirotrichs (mainly diplodinia with an average size of $132 \mu \mathrm{m} \times 66 \mu \mathrm{m})$.

\subsection{Statistical analysis}

Data was analyzed to explore the effect of source (leaves) on in vitro methane production and other variables using MINITAB 17. The following model was used $Y_{i j}=\mu+A_{i}+\varepsilon_{i j i}$; where $Y_{i j}$ was individual observation, $\mu$ was general mean, $A_{i}$ was the effect of the treatments $(i=1-15)$ and $\varepsilon_{i j}$ was the experimental error. While, the effect of source (leaves), PEG addition and their interaction was determined using General Linear model

$Y_{i j k}=\mu+A_{i}+B_{j}+(A B)_{i j}+\varepsilon_{i j k}$

where, $Y_{i j}$ was individual observation, $\mu$ was general mean, $A_{i}$ was the effect of factor $A$ (leaves $i=15$ ), $B_{j}$ was the effect of factor $B(P E G ; j=2),(A B) i_{j}$ was the effect of interaction between factor $A$ and $B$ (source ${ }^{*} P E G$ ) and $\varepsilon_{i j k}$ represented the experimental error.

\section{Results}

The qualitative screening of phyto-sources (leaves) from Hiamalyan regions of Uttarakhand in the present study (Table S1) revealed the presence of tannin in 12 (80\%) out of 15 samples. Similarly, most of the samples were also found positive for flavanoids (66\%) and terpenoids (94\%); however, none of the sample contained saponin or phlobatannins (Table S1). Qualitative screening of the samples confirmed the presence of alkaloids and glycosides in one and three samples, respectively.

The chemical composition, phenol and tannin (hydrolyzable-HT and condensed-CT) content of phyto-samples in the present study are presented in Table S2. The crude protein in leaves varied between 65.9 (Berberis lycium) to 172 (Artemisia vulgaris) $\mathrm{g} / \mathrm{kg}$ DM with an average of $8-11 \%$. The ether extract in the studied samples was consistently between 4 and 6\%, except, Prunus persica (8.07\%) and Punica granatum (8.04\%). Similarly, the ash content was also consistent among the samples and reported in the range of $9-11 \%$. The fibre fraction (NDF and ADF) was highly variable among the studied samples. The phytosources such as Pittosporum eriocarpum, Asparagus racemosus, Dalmori, Berberis lycium and Acacia catechu contain appreciable NDF content; whilst ADF was reported high in Lannea coromandelica followed by Berberis lyceum, Pittosporum eriocarpum, Juglans regia, Premna mollissima and 
Asparagus racemosus. Among the studied samples, Melia azedarach contain maximum condensed tannin $(78.7 \mathrm{~g} /$ $\mathrm{kg}$ ). The phenolic content of some of the phytosources (Punica granatum, Xanthoxylum alatum and Terminalia chebula) contains a substantial amount of phenolic compound. The phyto-sources such as Melia azedarach, Artemisia vulgaris, Pittosporum eriocarpum, Zanthoxylum alatum and Berberis lycium also possess an appreciable quantity of condensed tannin. Few phyto-sources such as Terminalia chebula, Punica granatum, Zanthoxylum alatum and Acacia catechu were found a promising source of hydrolyzable tannin. The leaves from Prunus domestica and Berberis lycium contain both condensed and hydrolysable tannin in almost equal proportion; however the overall level of tannin was low.

The large variation $(p<0.05)$ in total gas production ( $\mathrm{mL} / 200 \mathrm{mg} \mathrm{DM})$ among the samples revealed the different fermentation characteristics of the studied phytosources in this study. Phyto-sources such as Juglans regia, Terminalia chebula and Berberis lycium produced minimum gas during incubation; while on the other hand leaves from Punica granatum, Acacia catechu and Artemisia vulgaris produced maximum gas (Table 1). The PEG addition (PEG-6000) in 1:2 attenuated the adverse effect of tannin in the present study and increased the gas production ( $p<0.005$, Figure S1); however, the extent of increase in gas production was not uniform across the samples.

In the present study, a large variation $(p<0.05)$ in methane production $(\mathrm{mL} / 200 \mathrm{mg})$ was recorded. There was not a definite trend of methane production with respect to condensed and hydrolyzable tannin content, nevertheless the phyto-sources such as Pittosporum eriocarpum, Prunus domestica and Berberis lycium which contained both CT and $\mathrm{HT}$ in almost equal proportion produced comparatively less methane than those phyto-sources with appreciable amounts of either $\mathrm{CT}$ or $\mathrm{HT}$ (Table 1). The interaction of the source (leaves) with PEG in the present study was significant $(p<0.05)$ and an average increase of $41 \%$ was recorded irrespective of the sources (Figure $S 1$ ).

A significant $(p<0.05)$ variation in total volatile fatty acid (TVFA) production $(\mathrm{mM} / \mathrm{dL}$ ) was recorded in the present study. Among the samples Prunus domestica, which contained both CT and $\mathrm{HT}$ in equal proportion tended to produce least TVFA as compared to those which contained an appreciable amount of either CT (Artemisia vulgaris) or $\mathrm{HT}$ (Punica granatum and Acacia catechu). The interaction of the source with PEG for TVFA production proved significant $(p<0.05)$ in the present study. Increase in TVFA
Table 1 Effect of plant leaves and PEG addition on in vitro gas and methane production

\begin{tabular}{|c|c|c|c|c|c|c|c|c|}
\hline \multirow{3}{*}{$\begin{array}{l}\text { Plant leaves } \\
\text { Pittosporum eriocarpum }\end{array}$} & \multirow{2}{*}{\multicolumn{2}{|c|}{$\begin{array}{l}\begin{array}{l}\text { Total gas } \\
(\mathrm{mL} / 200 \mathrm{mg} \mathrm{DM})\end{array} \\
-\mathrm{PEG}+\mathrm{PEG}\end{array}$}} & \multirow{3}{*}{$\begin{array}{l}\% \\
\text { Increase } \\
\text { in gas } \\
12.5\end{array}$} & \multirow{2}{*}{\multicolumn{2}{|c|}{$\begin{array}{l}\text { Methane (mL) } \\
\text {-PEG + PEG }\end{array}$}} & \multirow{3}{*}{$\begin{array}{l}\text { \% increase } \\
\text { in Methane } \\
41.0\end{array}$} & \multicolumn{2}{|c|}{$\begin{array}{l}\text { Methane } \\
\text { (\% of TG) }\end{array}$} \\
\hline & & & & & & & \multirow[b]{2}{*}{9.50} & \multirow[b]{2}{*}{12.0} \\
\hline & $24.0^{\text {ef }}$ & $27.0^{g}$ & & $2.29^{\mathrm{e}}$ & $3.23^{\mathrm{e}}$ & & & \\
\hline Asparagus racemosus & $38.8^{\mathrm{bc}}$ & $39.4^{\mathrm{cd}}$ & 1.55 & $2.98^{\text {de }}$ & $4.71^{\text {de }}$ & 58.1 & 7.70 & 12.0 \\
\hline Prunus domestica & $29.2^{\text {de }}$ & $35.6^{\text {def }}$ & 21.9 & $3.92^{\text {bcde }}$ & $7.69^{\mathrm{abc}}$ & 96.2 & 13.4 & 21.6 \\
\hline Prunus persica & $39.4^{b c}$ & $43.2^{\mathrm{bc}}$ & 9.64 & $7.80^{\mathrm{a}}$ & $9.29^{\mathrm{a}}$ & 19.1 & 19.8 & 21.5 \\
\hline Dalmori* & $31.0^{\mathrm{d}}$ & $34.2^{\text {ef }}$ & 10.3 & $5.85^{\mathrm{ab}}$ & $8.30^{\mathrm{ab}}$ & 41.9 & 18.9 & 24.1 \\
\hline Juglans regia & $13.8^{\mathrm{g}}$ & $15.4^{i}$ & 11.6 & $3.09^{\text {cde }}$ & $4.20^{\text {de }}$ & 35.9 & 22.4 & 27.2 \\
\hline Melia azedarach & $28.6^{\mathrm{de}}$ & $32.8^{f}$ & 14.7 & $4.65^{\text {bcde }}$ & $5.70^{\text {bcde }}$ & 22.6 & 16.3 & 17.2 \\
\hline Terminalia chebula & $21.6^{f}$ & $24.0^{\mathrm{gh}}$ & 11.1 & $2.65^{\mathrm{de}}$ & $3.30^{\mathrm{e}}$ & 24.5 & 12.3 & 13.9 \\
\hline Berberis lycium & $21.2^{f}$ & $21.6^{\mathrm{h}}$ & 1.89 & $2.45^{\mathrm{e}}$ & $3.20^{\mathrm{e}}$ & 30.6 & 11.6 & 14.7 \\
\hline Zanthoxylum alatum & $30.4^{d}$ & $33.0^{\text {ef }}$ & 8.55 & $3.22^{\text {cde }}$ & $4.78^{\text {cde }}$ & 48.4 & 10.6 & 14.5 \\
\hline Premna mollissima & $34.8^{\mathrm{cd}}$ & $44.2^{\mathrm{bc}}$ & 27.0 & $5.13^{b c d}$ & $6.80^{\mathrm{abcd}}$ & 32.6 & 14.7 & 15.3 \\
\hline Artemisia vulgaris & $43.4^{b}$ & $58.4^{\mathrm{a}}$ & 34.6 & $5.61^{\mathrm{abc}}$ & $8.80^{\mathrm{a}}$ & 56.9 & 12.9 & 15.1 \\
\hline Punica granatum & $52.0^{\mathrm{a}}$ & $54.2^{\mathrm{a}}$ & 4.23 & $6.11^{\mathrm{ab}}$ & $6.40^{\mathrm{abcd}}$ & 4.75 & 11.8 & 11.9 \\
\hline Acacia catechu & $43.6^{b}$ & $47.4^{b}$ & 8.72 & $6.31^{\mathrm{ab}}$ & $8.80^{\mathrm{a}}$ & 39.5 & 14.5 & 18.6 \\
\hline Lannea coromandelica & $31.0^{d}$ & $37.8^{\text {de }}$ & 21.9 & $2.98^{\mathrm{de}}$ & $4.9^{\text {cde }}$ & 64.4 & 9.60 & 13.0 \\
\hline SEM & 1.78 & 1.40 & - & 0.722 & 0.836 & - & - & - \\
\hline$p$ value & $<0.001$ & $<0.001$ & - & $<0.001$ & $<0.001$ & - & - & - \\
\hline \multicolumn{9}{|c|}{ Interaction (source ×PEG) } \\
\hline SEM & 0.288 & & - & 0.918 & & - & - & - \\
\hline$p$ value & 0.039 & & - & $<0.001$ & & - & - & - \\
\hline
\end{tabular}

Mean values bearing different superscripts in a column differ significantly $(p<0.05)$

*Scientific name could not be ascertained 
production was found when PEG was included with the source and their value ranged from 0.909 to $23 \%$.

Similarly, the effect of sources on Ammonia Nitrogen was also significant $(p<0.001)$. The effect of different phyto-sources on concentration of Ammonia Nitrogen $(\mathrm{mg} / \mathrm{dL}$ ) varied between 13.7 and $40.6 \mathrm{mg} / \mathrm{dL}$ (Table 2). In the present study, significant reduction in Ammonia Nitrogen concentration was observed with some phytosources (Juglans regia, Terminalia chebula and Prunus persica). There was a considerable decrease in ammonia- $\mathrm{N}$ concentration with Acacia catechu and Lannea coromandelica containing high concentration of HT while a slight decrease was observed with other phyto-sources (Premna mollissima, Prunus domestica, Punica granatum) compared with PEG supplemented phyto-sources. Slight increment in ammonia nitrogen concentration was observed with the inclusion of PEG 6000.

Total protozoal $\left(\times 10^{3} / \mathrm{mL}\right)$ numbers varied $(p<0.05)$ among the fermented in vitro incubation medium and recorded the lowest in Berberis lyceum; whilst highest numbers were found in the incubation medium of Acacia catechu (Table 3). The present study showed the less number of protozoa from the incubation of phyto-sources that contained both condensed tannin (CT) and hydrolyzable tannin $(\mathrm{HT})$ than those contained either $\mathrm{CT}$ or HT. The interaction of source $\times$ PEG was found significant $(p<0.05)$ confirming the attenuation of adverse impact of tannin on rumen protozoa.
The inclusion of PEG with source substantially increased overall protozoal count (Fig. S1). Results from the study indicated that the addition of PEG did not have a uniform increase in entodinomorph $\left(\times 10^{3} / \mathrm{mL}\right)$ numbers. The increase in entodinomorph numbers due to PEG addition was more prominent in the phyto-sources containing both condensed tannin (CT) and hydrolyzable tannin $(\mathrm{HT})$ in appreciable quantity than those either contained $\mathrm{CT}$ or HT. The study also confirmed that entodinomorph ciliates were more vulnerable to the tanniferous phytosources than the holotrichs.

\section{Discussion}

Globally, the different approaches for ruminal methane amelioration through manipulation in feeding are being practiced. The phyto-sources possessing bioactive molecules are one of the effective ways of ameliorating methane emission. The desirable effect by the inclusion of plant secondary metabolites (PSM) containing phytosources are achieved through direct or indirect action on the rumen metahnogens and protozoa, control of gut pathogens, improved digestibility, feed efficiency and less ruminal protein degradation [13]. As PSM-containing phyto-sources are not uniformly distributed among various geographical areas and confined to specific regions,
Table 2 Effect of plant leaves and PEG addition on TVFA and ammonia-N

\begin{tabular}{|c|c|c|c|c|c|c|}
\hline \multirow[t]{2}{*}{ Tree leaves } & \multicolumn{2}{|c|}{ TVFA (mM/dL) } & \multirow[t]{2}{*}{$\%$ increase } & \multicolumn{2}{|c|}{$\mathrm{NH}_{3}-\mathrm{N}(\mathrm{mg} / \mathrm{dL})$} & \multirow[t]{2}{*}{$\%$ increase } \\
\hline & $-P E G$ & + PEG & & $-P E G$ & + PEG & \\
\hline Pittosporum eriocarpum & $10.2^{\mathrm{bcd}}$ & $11.0^{\text {bcdef }}$ & 7.84 & $24.6^{c}$ & $24.1^{\mathrm{de}}$ & - \\
\hline Asparagus racemosus & $10.1^{\mathrm{bcd}}$ & $10.3^{\text {efg }}$ & 1.98 & $23.8^{\mathrm{cd}}$ & $24.9^{\mathrm{cd}}$ & 4.62 \\
\hline Prunus domestica & $9.06^{d}$ & $10.0^{\mathrm{fg}}$ & 10.3 & $16.2^{\mathrm{ef}}$ & $20.2^{\text {def }}$ & 24.6 \\
\hline Prunus persica & $10.4^{\mathrm{abcd}}$ & $12.8^{\mathrm{a}}$ & 23.0 & $15.4^{\mathrm{ef}}$ & $16.0^{\mathrm{fg}}$ & 3.89 \\
\hline Dalmori & $10.1^{\mathrm{bcd}}$ & $10.4^{\text {defg }}$ & 2.97 & $15.6^{\mathrm{ef}}$ & $17.6^{\mathrm{fg}}$ & 12.8 \\
\hline Juglans regia & $11.2^{\mathrm{abc}}$ & $11.7^{\mathrm{abcd}}$ & 4.46 & $14.5^{f}$ & $14.6^{g}$ & - \\
\hline Melia azedarach & $9.28^{c d}$ & $9.60^{\mathrm{g}}$ & 3.44 & $15.9^{\mathrm{ef}}$ & $19.0^{\text {efg }}$ & 19.4 \\
\hline Terminalia chebula & $10.0^{\mathrm{bcd}}$ & $11.1^{\text {bcdef }}$ & 11.0 & $13.7^{f}$ & $16.0^{\mathrm{fg}}$ & 16.7 \\
\hline Berberis lycium & $9.80^{\mathrm{bcd}}$ & $10.8^{\text {bcdefg }}$ & 10.2 & $15.7^{\mathrm{ef}}$ & $16.5^{\mathrm{fg}}$ & 5.09 \\
\hline Zanthoxylum alatum & $9.86^{\mathrm{bcd}}$ & $10.9^{\text {bcdefg }}$ & 10.5 & $16.5^{\mathrm{ef}}$ & $17.3^{\mathrm{fg}}$ & 4.84 \\
\hline Premna mollissima & $10.0^{\mathrm{bcd}}$ & $10.6^{\text {cdefg }}$ & 6.00 & $26.3^{c}$ & $30.0^{c}$ & 14.0 \\
\hline Artemisia vulgaris & $11.9^{\mathrm{a}}$ & $12.1^{\mathrm{ab}}$ & 1.68 & $39.7^{\mathrm{a}}$ & $36.1^{\mathrm{b}}$ & - \\
\hline Punica granatum & $10.9^{\mathrm{ab}}$ & $12.0^{\mathrm{abc}}$ & 10.0 & $40.6^{\mathrm{a}}$ & $44.2^{\mathrm{a}}$ & 8.86 \\
\hline Acacia catechu & $10.8^{\mathrm{ab}}$ & $11.6^{\text {abcde }}$ & 7.40 & $33.8^{\mathrm{b}}$ & $43.4^{\mathrm{a}}$ & 28.4 \\
\hline Lannea coromandelica & $11.0^{\mathrm{ab}}$ & $11.1^{\mathrm{bcdef}}$ & 0.909 & $19.8^{\mathrm{de}}$ & $29.7^{c}$ & 50.0 \\
\hline SEM & & 0.396 & - & 1.34 & 1.43 & - \\
\hline$p$ value & $<0.001$ & $<0.001$ & - & $<0.001$ & $<0.001$ & - \\
\hline \multicolumn{7}{|l|}{ Interaction (source × PEG) } \\
\hline SEM & 0.288 & & - & 0.918 & & - \\
\hline$p$ value & 0.039 & & - & $<0.001$ & & - \\
\hline
\end{tabular}

Mean values bearing different superscripts in a column differ significantly $(p<0.05)$ 
Table 3 Rumen protozoa $\left(\times 10^{3}\right)$ as influenced by source (leaves) and PEG addition

\begin{tabular}{|c|c|c|c|c|c|c|c|c|c|c|c|c|}
\hline \multirow[t]{2}{*}{ Tree leaves } & \multicolumn{2}{|c|}{ Entodina $\left(\times 10^{3}\right)$} & \multirow[t]{2}{*}{$\%$ Increase } & \multicolumn{2}{|c|}{ Isotricha $\left(\times 10^{3}\right)$} & \multicolumn{2}{|c|}{$\begin{array}{l}\text { Dasytricha } \\
\left(\times 10^{3}\right)\end{array}$} & \multicolumn{2}{|c|}{$\begin{array}{l}\text { Holotricha } \\
\left(\times 10^{3}\right)\end{array}$} & \multicolumn{2}{|c|}{ Total $\left(\times 10^{5}\right)$} & \multirow[t]{2}{*}{$\%$ Increase } \\
\hline & $-\mathrm{PEG}$ & + PEG & & $-P E G$ & + PEG & $-P E G$ & + PEG & $-\mathrm{PEG}$ & + PEG & $-\mathrm{PEG}$ & + PEG & \\
\hline Pittosporum eriocarpum & $14.5^{\mathrm{d}}$ & $16.6^{\text {de }}$ & 14.5 & $0.3^{b c}$ & $0.5^{\text {bcde }}$ & $0.6^{\mathrm{a}}$ & $0.6^{\mathrm{a}}$ & $0.9^{\mathrm{abc}}$ & $1.2^{\mathrm{b}}$ & $15.4^{\mathrm{cd}}$ & $17.8^{d}$ & 15.6 \\
\hline Asparagus racemosus & $17.2^{c}$ & $19.1^{\mathrm{bc}}$ & 11.0 & $0.6^{\mathrm{abc}}$ & $1.1^{\mathrm{ab}}$ & $0.4^{\mathrm{ab}}$ & $0.6^{\mathrm{a}}$ & $0.9^{\mathrm{ab}}$ & $1.8^{\mathrm{a}}$ & $18.1^{\mathrm{b}}$ & $20.9^{b c}$ & 15.5 \\
\hline Prunus domestica & $11.8^{\mathrm{e}}$ & $14.4^{f}$ & 22.0 & $0.4^{\mathrm{bc}}$ & $0.5^{\text {bcde }}$ & $0.2^{\text {bcde }}$ & $0.3^{\mathrm{abcd}}$ & $0.6^{\mathrm{bcd}}$ & $0.9^{b c}$ & $12.5^{\mathrm{e}}$ & $15.3^{\mathrm{e}}$ & 22.4 \\
\hline Prunus persica & $12.6^{\text {de }}$ & $17.0^{\text {cde }}$ & 34.9 & $0.2^{\mathrm{bc}}$ & $0.1^{\mathrm{e}}$ & $0.01^{\mathrm{cd}}$ & $0.09^{\text {de }}$ & $0.3^{d}$ & $0.3^{d c}$ & $13.0^{\mathrm{e}}$ & $17.3^{d}$ & 33.1 \\
\hline Dalmori & $13.4^{\mathrm{de}}$ & $15.1^{\text {ef }}$ & 12.7 & $0.5^{\mathrm{abc}}$ & $0.07^{e}$ & $0.2^{\mathrm{bcd}}$ & $0.05^{\mathrm{e}}$ & $0.7^{\mathrm{abcd}}$ & $0.1^{\mathrm{e}}$ & $14.1^{\text {de }}$ & $15.3^{e}$ & 8.51 \\
\hline Juglans regia & $20.8^{\mathrm{a}}$ & $22.0^{\mathrm{a}}$ & 5.77 & $0.2^{\mathrm{bc}}$ & $0.2^{\text {cde }}$ & $0.2^{\mathrm{bcd}}$ & $0.1^{\text {cde }}$ & $0.5^{\mathrm{bcd}}$ & $0.4^{\text {cde }}$ & $21.3^{\mathrm{a}}$ & $22.5^{\mathrm{ab}}$ & 5.63 \\
\hline Melia azedarach & $20.6^{a}$ & $21.9^{\mathrm{a}}$ & 6.31 & $0.1^{c}$ & $0.2^{\mathrm{de}}$ & $0.2^{\mathrm{bcd}}$ & $0.4^{\mathrm{abc}}$ & $0.3^{\mathrm{cd}}$ & $0.7^{\text {bcde }}$ & $21.0^{a}$ & $22.6^{\mathrm{ab}}$ & 7.62 \\
\hline Terminalia chebula & $20.5^{\mathrm{a}}$ & $21.8^{\mathrm{a}}$ & 6.34 & $0.1^{c}$ & $0.1^{\mathrm{a}}$ & $0.2^{\mathrm{bcd}}$ & $0.3^{\text {cde }}$ & $0.3^{d}$ & $0.5^{\text {cde }}$ & $20.9^{a}$ & $22.3^{\mathrm{ab}}$ & 6.70 \\
\hline Berberis lycium & $7.9^{f}$ & $11.9^{g}$ & 50.6 & $0.7^{\mathrm{abn}}$ & $1.4^{\text {cde }}$ & $0.01^{d}$ & $0.3^{\text {bcde }}$ & $0.4^{\mathrm{bcd}}$ & $0.6^{\text {cde }}$ & $8.4^{f}$ & $12.5^{f}$ & 48.8 \\
\hline Zanthoxylum alatum & $20.2^{\mathrm{ab}}$ & $22.4^{\mathrm{a}}$ & 10.9 & $0.5^{\mathrm{abc}}$ & $0.2^{\mathrm{abcde}}$ & $0.6^{\mathrm{a}}$ & $0.1^{\text {cde }}$ & $1.2^{\mathrm{a}}$ & $0.5^{\text {cde }}$ & $21.4^{\mathrm{a}}$ & $22.9^{\mathrm{a}}$ & 7.01 \\
\hline Premna mollissima & $13.6^{\mathrm{de}}$ & $20.4^{\mathrm{ab}}$ & 50.0 & $0.4^{\mathrm{bc}}$ & $0.7^{\mathrm{abcde}}$ & $0.2^{\mathrm{bc}}$ & $0.2^{\text {cde }}$ & $0.5^{\mathrm{bcd}}$ & $0.6^{\text {cde }}$ & $14.1^{\mathrm{de}}$ & $21.1^{\mathrm{ab}}$ & 49.6 \\
\hline Artemisia vulgaris & $18.0^{\mathrm{bc}}$ & $18.1^{\mathrm{cd}}$ & 0.56 & $0.5^{\mathrm{abc}}$ & $0.9^{\mathrm{abcd}}$ & $0.4^{\mathrm{ab}}$ & $0.5^{\mathrm{ab}}$ & $0.5^{\mathrm{bcd}}$ & $0.4^{\text {cde }}$ & $18.6^{\mathrm{b}}$ & $18.5^{\mathrm{d}}$ & 0.00 \\
\hline Punica granatum & $12.2^{\mathrm{e}}$ & $13.1^{\mathrm{fg}}$ & 17.0 & $0.2^{c}$ & $0.5^{\text {bcde }}$ & $0.2^{\mathrm{bcd}}$ & $0.9^{\mathrm{de}}$ & $0.3^{d}$ & $0.7^{\mathrm{bcd}}$ & $12.5^{\mathrm{e}}$ & $13.9^{\text {ef }}$ & 11.2 \\
\hline Acacia catechu & $21.5^{\mathrm{a}}$ & $21.9^{a}$ & 1.86 & $0.1^{\mathrm{c}}$ & $0.1^{\text {de }}$ & $0.2^{\mathrm{bcd}}$ & $0.2^{\text {cde }}$ & $0.3^{\mathrm{d}}$ & $0.7^{\text {cde }}$ & $21.9^{a}$ & $22.4^{\mathrm{ab}}$ & 2.28 \\
\hline Lannea coromandelica & $16.9^{c}$ & $18.6^{b c d}$ & 10.1 & $1.1^{\mathrm{a}}$ & $1.0^{\mathrm{abc}}$ & $0.3^{b c}$ & $0.3^{\text {bcde }}$ & $0.4^{\mathrm{bcd}}$ & $0.5^{\text {cde }}$ & $17.4^{\mathrm{b}}$ & $19.1^{\mathrm{cd}}$ & 9.77 \\
\hline SEM & 0.006 & 0.005 & - & 0.001 & 0.002 & 0.0005 & 0.0007 & 0.001 & 0.001 & 0.006 & 0.005 & - \\
\hline$p$ value & $<0.001$ & $<0.001$ & - & $<0.001$ & $<0.001$ & $<0.001$ & $<0.001$ & $<0.001$ & $<0.001$ & $<0.001$ & $<0.001$ & - \\
\hline \multicolumn{13}{|l|}{ Interaction (Source × PEG) } \\
\hline SEM & 0.004 & & - & 0.001 & & 0.0005 & & 0.001 & & 0.001 & & - \\
\hline$p$ value & $<0.001$ & & - & 0.004 & & $<0.001$ & & $<0.001$ & & $<0.001$ & & - \\
\hline
\end{tabular}

Mean values bearing different superscripts in a column differ significantly $(p<0.05)$

a Percent increase represents increase with PEG addition compared to without PEG

therefore, there is a need to broaden the list of phytosources with established methane ameliorative effect if incorporated in animal diets. Most of the phyto-sources used in this study hardly been studied for their impact on rumen methanogenesis and the incorporation of promising sources at the appropriate level in diet will enable us in reducing methane emission from the livestock in hilly states such as Assam, Uttarakhand, Himachal Pradesh and Jammu \& Kashmir.

Phyto-sources except Asparagus racemosus, Premna mollissima and Dalmori in the present study found positive for the tannins presence. The previous findings [14] substantiate our results for the presence of tannins and alkaloids in Pittosporum eriocarpum. Asparagus racemosus has shown good potential in reducing methane production. The anti-methanogenic property of Asparagus racemosus was attributed to flavonoid content which is also known for the anti-protozoal action ([15]. Previous findings [16] also corroborate our results for the presence of flavonoid in Punica granatum.

Tannins, flavonoids and terpenoids were three major secondary metabolites abundantly distributed in the studied phyto-sources. Flavanoids holds good potential to be used as bio-active phyto-agents for manipulating the rumen fermentation. In vitro and in vivo studies [16-18] established that flavonoid extracts helps in correcting animal production inefficiencies by reducing methane emission. Though we have not characterized the flavanoids in the present study, nevertheless it is well documented that different types of flavanoids induce variable impact on gas production. The reduction in methane production due to the flavanoids containing phyto-sources could be attributed to the reduction in ciliate protozoa numbers. Previous study [16] confirmed a reduction of about $60 \%$ in protozoa due to the flavanoidsrich plant extract. However, in a study [19], a direct impact of flavonoids on methanogens was also reported.

$A$ reduction in methane emission due to phenolic sources was also reported previously [20, 21]. However, the reduction in methane with various phenolic sources is quite variable, attributed to the structural diversity and interaction [22]. Further, the variable dose response also held responsible for the incongruity [23]. Tannin content (CT) in Artemisia vulgaris was within the previous reported range [24]; whilst the CT content in Melia azedarach was higher than reported earlier [25]. This variability in tannins content could be explained on the basis of parts used for tannins estimation. For example, we have used the leaves of Melia azedarach for tannins estimation; whilst Gemeda 
and Hassen [25] used a mixture of leaves and stem. Our results are in agreement with previous findings [26].

The large variation in total gas production indicated different fermentation characteristics of phyto-sources in the present study. Sources such as Juglans regia, Terminilia chebula and Berberis lycium containing condensed (CT) and hydrolyzable tannins (HT) produced lesser gas. The decrease in gas production from these sources may be due to the negative impact of high tannins and phenolic compounds on fermentation characteristics. Tannins have the ability to bind protein through hydrogen bonding between phenolic and carbonyl groups and thereby exert impact on the rumen microbes [27-29]. Our results are in agreement with the previous findings that combination of condensed (CT) and hydrolyzable tannins (HT) are more effective in reducing methane production as compared to individual [30]. Further, the differences in gas production can be due to the difference in the chemical structure of cell wall [29] and molecular weight of tannins. A decrease in gas production from Terminalia chebula might be due to the high levels of plant secondary compounds that lead to the toxic impact on ruminal bacteria. The plausible cause for the decrease in gas production due to tannins may be the interaction between tannins and feed components such as protein and carbohydrates [31, 32]. PEG (tannin binding agent) neutralizes the effect of tannins [9]. PEG binds to tannins and inhibits plant secondary compounds to interact with other macromolecules such as carbohydrate and protein and prevent their anti-microbial properties. Kondo et al. [33] reported an increase in gas production due to PEG addition.

Enteric methane production primarily depends on the quantity and quality of the basal diet [34]. The difference in fibre fractions and tannins content affect methane production [35]. Tannins reduce methane emission in both direct and indirect ways [36]. Tannins directly target rumen methanogens or kill the protozoa associated with rumen methanogens. Further, inhibition of fiber degradation lead to a shift in fermentation that resulted into less methane. Earlier reports [30,31] strengthen our findings that $\mathrm{CT}$ and $\mathrm{HT}$ both can lead to lower methane emission. The impact of CT on methane through reduction in fiber digestion is more pronounced than HT. This is due to the higher resistance of the $\mathrm{CT}$ aromatic structure for microbial degradation than the HT [28]. The decrease in methane production on the incorporation of tannins in also been reported by many others [37, 38]. A meta-analysis [31] revealed that increase in tannins concentration consistently suppressed methane production both in vitro and in vivo. Many [39-41] reported a significant reduction in methane with tannins supplementation. On the other hand, a non-significant effect of tannins on methane production also reported $[22,34]$. This deviation in methane reducing impact attributed to the variable chemical structure and concentration of tannins. Patra and Saxena [42] reported that tannin acts as a toxicant to methanogens, cause a decline in organic matter (OM) digestion and reduces acetate and butyrate production (i.e. reduce fibre digestibility).

The VFA production in rumen mainly depends on the degree and rate of fermentation [43]. Reduction in total volatile fatty acid (TVFA) could be attributed to the formation of tannins-protein and tannins-carbohydrate complexes which are less degradable [44] or toxicity to the rumen microbes [45]. It has also been reported that the inhibition of fibre degradation shifts fatty acid composition away from acetate, which results in less production of hydrogen and thus less methane fermentation [46]. Krueger et al. [47] reported no or little impact of low tannins on acetate, propionate and butyrate concentration, whereas present study revealed a significant effect $(p<0.001)$ of tannin on these parameters. However, in present study, tannins effect on TVFA was less prominent than effect on methane production. This indicated that methane production in this study was not due to the reduction in fibre degradation.

It has been evidenced that there is a reduction in ruminal ammonia concentration $[38,48]$ by supplementing dietary tannins. Some of the phyto-sources (Terminalia chebula, Berberis lycium and Prunus domestica) considerably decreased ammonia-N concentration. Usually, HT and proteins forms complexes at $\mathrm{pH} 3-4$, but appreciable amount of complexes are also formed under typical rumen $\mathrm{pH}$ of 6-7 [49]. Reduction in protozoal population in present study caused the reduction in ammonia-N. Our results corroborated with earlier finding [41], reported that a concurrent decrease in ammonia and protozoal population.

Earlier study [20] reported that an increasing level of tannins reduce protozoa in goat rumens. Protozoa are accountable for interspecies $\mathrm{H}_{2}$ transfer and therefore any reduction in ciliates would lead to a reduction in methane $[50,51]$. It is quite possible that condensed tannins binds to the cell surface and induce toxicity to the protozoa [53]. However, saponins interfere with sterols in the protozoal cell wall [52]. However, reduction in protozoal counts always not accompanied with reduction in methane. This established that there is a weak association between protozoa and methanogenesis [41].

The increase in entodinomorphs with PEG supplementation was more prominent in phytosources containing both CT and HT. Sliwinski et al. [54] reported a significant effect of HT on protozoal count, whereas others [55] found that $\mathrm{HT}$ is less inhibitory as compared to $\mathrm{CT}$. These studies established that methanogenesis is not essentially related to the density of protozoa, and only a small proportion of total methane production was attributed to the presence 
of methanogens attached with the ciliate protozoa [56]. Similar to our study, a previous report [46] also concluded that the direct relationship between dietary tannins and protozoa is poor.

\section{Conclusion}

In the present study, we investigated the methane reduction potential of fifteen phyto leaves from foothill of Himalaya using in vitro technique and identified few promising sources that can be used in animal diet as methane suppressing agents. From the study, it can be concluded that Prunus domestica, Berberis lycium and Terminalia chebula contain appreciable tannin content and potential antimethanogenic phyto-sources. However, further in vivo studies with selected sources are warranted in order to optimize the incorporation level in the diet.

Acknowledgements Authors sincerely acknowledge the financial support from the Department of Science and Technology (DST), Govt. of India and Japan Society for the Promotion of Science (JSPS) under an international collaborative project (DST/INT/JSPS/P-205/2015) on "Methane mitigation using unexplored phyto-sources in ruminants and their effect on rumen microbial diversity".

Funding The study was conducted with the financial support from the Department of Science and Technology (DST), Govt. of India (Grant Number DST/INT/JSPS/P-205/2015) under DST-JSPS collaborative project "Methane mitigation using unexplored phyto-sources in ruminants and their effect on rumen microbial diversity".

\section{Compliance with ethical standards}

Conflict of interest The authors declare that they have no conflict of interest.

\section{References}

1. Solomon S, Qin D, Manning M, Averyt K, Marquis M (2007) Climate change 2007-the physical science basis: working group I contribution to the fourth assessment report of the IPCC, vol 4. Cambridge University Press, Cambridge

2. Johnson KA, Johnson DE (1995) Methane emissions from cattle. J Anim Sci 73:2483-2492

3. Nagaraja TG, Newbold CJ, Van Nevel CJ, Demeyer DI (1997) Manipulation of ruminal fermentation. In: Hobson PN, Stewart CS (eds) The rumen microbial ecosystem. Chapman and Hall, London, pp 523-632

4. Edeoga HO, Okwu DE, Mbaebie BO (2005) Phytochemical constituents of some Nigerian medicinal plants. Africa J Biotechnol 4(7):685-688

5. Mustapha Z, Harun H (2015) Phytochemical constituents in leaves and callus of Ficus deltoidea Jack var. Kunstleri (King) Corner. Walailak J Sci Technol 12(5):471-479

6. Makkar HPS (2003) Quantification of tannins. Joint FAO/IAEA, Division of Nuclear Techniques in Food and Agriculture, Kluwer Academic Publishers, Dordrecht
7. Van Soest PJ, Robertson JB, Lewis BA (1991) Methods for dietary fibre, neutral detergent fibre and non-starch polysaccharides in relation to animal nutrition. J Dairy Sci 74:3583-3597

8. Menke KH, Raab L, Salewski A, Steingass H, Fritz D, Schneider W (1979) The estimation of digestibility and metabolizable energy content of ruminant feeding stuffs from the gas production when they are incubated with rumen inoculum in vitro. J Agric Sci 93:217-222

9. Makkar HPS, Blummel M, Becker K (1995) Formation of complexes between polyvinyl pyrrolidones or polyethylene glycols and tannins, and their implication in gas production and true digestibility in in vitro techniques. Br J Nutr 73:897-913

10. Conway HJ (1957) Microdiffusion analysis and volumetric error, 4th edn. Crossby Lockwood, London, UK

11. Barnett AJG, Reid RL (1957) Studies on production of volatile fatty acids from grass by rumen liquor in an artificial rumen. $J$ Agric Sci 48:315-321

12. Hungate RE (1966) The rumen and its microbes. Academic Press, London, pp 26-36

13. Durmic Z, Blache D (2012) Bioactive plants and plant products: effects on animal function, health and welfare. Anim Feed Sci Technol 176(1-4):150-162

14. Semwal P, Anthwal P, Kapoor T, Thapliyal A (2014) Preliminary investigation of phytochemicals of Saussurea obvallata (Brahm kamal) and Pittosporum eriocarpum (Agni) endangered medicinal plant species of Uttarakhand. Int J Pharmacogn 1:266-269

15. Alok S, Jain SK, Verma A, Kumar M, Mahor A, Sabharwal M (2013) Plant profile, phytochemistry and pharmacology of Asparagus racemosus (Shatavari): a review. Asian Pac J Trop Dis 3(3):242-251

16. Kim ET, Guan LL, Lee SJ, Lee SM, Lee SS, Lee ID, Lee SK, Lee SS (2015) Effects of flavonoid-rich plant extracts on in vitro ruminal methanogenesis, microbial populations and fermentation characteristics. Asian Australas J Anim Sci 28(4):530-537

17. Oskoueian E, Abdullah N, Oskoueian A (2013) Effects of flavonoids on rumen fermentation activity, methane production, and microbial population. Biomed Res Int. https://doi. org/10.1155/2013/349129

18. Becker PM, Van Wikselaar PG, Franssen MCR, DeVos RCH, Hall RD, Beekwilder J (2014) Evidence for a hydrogen-sink mechanism of $(+)$ catechin-mediated emission reduction of the ruminant greenhouse gas methane. Metabolomics 10:179-189

19. Patra AK, Saxena J (2010) A new perspective on the use of plant secondary metabolites to inhibit methanogenesis in the rumen. Phytochem 71(11-12):1198-1222

20. Animut G, Goetsch AL, Puchala R, Patra AK, Sahlu T, Varel VH, Wells J (2008) Methane emission by goats consuming diets with different levels of condensed tannins from Lespedeza. Anim Feed Sci Technol 144:212-227

21. Jayanegara A, Wina $E$, Soliva $C R$, Marquardt $S$, Kreuzer $M$, Leiber $F$ (2011) Dependence of forage quality and methanogenic potential of tropical plants on their phenolic fractions as determined by principal component analysis. Anim Feed Sci Technol 163:231-2430

22. de Oliveira SG, Berchielli TT, dos Santos PM, Primavesi O, Frighetto R, Lima MA (2007) Effect of tannin levels in sorghum silage and concentrate supplementation on apparent digestibility and methane emission in beef cattle. Anim Feed Sci Technol 135(3-4):236-248

23. Rochfort S, Parker AJ, Dunshea FR (2008) Plant bioactives for ruminal health and productivity. Phytochem 69:299-322

24. Msaada K, Salem N, Bachrouch O, Bousselmi S, Tammar S, Alfaify A, Al Sane K, Ammar WB, Azeiz S, Brahim AH, Hammami M, Selmi S, Limam F, Marzouk B (2015) Chemical composition and antioxidant and antimicrobial activities of wormwood 
(Artemisia absinthium L.) essential oils and phenolics. J Chem. https://doi.org/10.1155/2015/804658

25. Gemeda BS, Hassen A (2015) Effect of tannin and species variation on in vitro digestibility, gas, and methane production of tropical browse plants. Asian Australas J Anim Sci 28(2):188-199

26. Millogo-Kone H, Guissou IP, Nacoulma O, Traore AS (2008) Comparative study of leaf and stem bark extracts of Parkia biglobosa against Enterobacteria. Afr JTrad Complement Altern Med 5(3):238-243

27. Makkar HPS, Blummel M, Becker K (1995) In vitro effects of and interactions between tannins and saponins and the fate of tannins in the rumen. J Sci Food Agric 69:481-493

28. McSweeney CS, Palmer B, McNeill DM, Krause DO (2001) Microbial interactions with tannins: nutritional consequences for ruminants. Anim Feed Sci Technol 91:83-93

29. Tiemann TT, Lascano CE, Kreuzer M, Hess HD (2008) The ruminal degradability of fibre explains part of the low nutritional value and reduced methanogenesis in highly tanniniferous tropical legumes. J Sci Food Agric 88:1794-1803

30. Bhatta R, Uyeno Y, Tajima K, Takenaka A, Yabumoto Y, Nonaka $E O$, Kurihara M (2009) Difference in the nature of tannins on in vitro ruminal methane and volatile fatty acid production and on methanogenic archaea and protozoal populations. J Dairy Sci 92:5512-5522

31. Jayanegara A, Leiber F, Kreuzer M (2012) Meta analysis of the relationship between dietary tannin level and methane formation in ruminants from in vivo and in vitro experiments. J Anim Physiol Anim Nutr 96:365-375

32. Mueller-Harvey I (2006) Unraveling the conundrum of tannins in animal nutrition and health. J Sci Food Agric 86:2010-2037

33. Kondo M, Hirano Y, Kita K, Jayanegara A, Yokota H (2014) Fermentation characteristics, tannin contents and in vitro ruminal degradation of green tea and black tea by-products ensiled at different temperatures. Asian Australas J Anim Sci 27:937-945

34. Beauchemin KA, McGinn SM, Martinez TF, McAllister TA (2007) Use of condensed tannin extract from quebracho trees to reduce methane emissions from cattle. J Anim Sci 85(8):1990-1996

35. Jayanegara A, Goel G, Makkar HPS, Becker K (2015) Divergence between purified hydrolysable and condensed tannin effects on methane emission, rumen fermentation and microbial population in vitro. Anim Feed Sci Technol 209:60-68

36. Tavendale MH, Meagher MP, Pacheco D, Walker N, Attwood GT, Sivakumaran S (2005) Methane production from in vitro incubations with Lotus penduculatus and Medigo sativa and effects of extractable condensed tannin fractions on methanogenesis. Anim Feed Sci Technol 123:403-419

37. Sebata A, Ndlovu LR, Dube JS (2011) Chemical composition, in vitro dry matter digestibility and in vitro gas production of five woody species browsed by Matebele goats (Capra hircus L.) in a semi-arid savanna, Zimbabwe. Anim Feed Sci Technol 170:122-125

38. Singh S, Kushwaha BP, Nag SK, Mishra AK, Singh A, Anele UY (2012) In vitro ruminal fermentation, protein and carbohydrate fractionation, methane production and prediction of twelve commonly used Indian green forages. Anim Feed Sci Technol 178:2-11

39. Hess HD, Tiemann TT, Noto F, Carulla JE, Kreuzer M (2006) Strategic use of tannins as means to limit methane emission from ruminant livestock. Int Congr Ser 1293:164-167

40. Tan HY, Sieo CC, Abdullah N, Liang JB, Huang XD, Ho YW (2011) Effects of condensed tannins from Leucaena on methane production, rumen fermentation and populations of methanogens and protozoa in vitro. Anim Feed Sci Technol 169:185-193

41. Bhatta R, Saravanan M, Baruah L, Sampath KT (2012) Nutrient content, in vitro ruminal fermentation characteristics and methane reduction potential of tropical tannin-containing leaves. J Sci Food Agric 92(15):2929-2935

42. Patra AK, Saxena J (2011) Exploitation of dietary tannins to improve rumen metabolism and ruminant nutrition. J Sci Food Agric 91:24-37

43. Dijkstra J, Kebreab E, Bannink A, France J, Lopez S (2005) Application of the gas production technique to feed evaluation systems for ruminants. Anim Feed Sci Technol 123:561-578

44. Makkar HPS (2005) In vitro gas methods for evaluation of feeds containing phytochemicals. Anim Feed Sci Technol 123:291-302

45. Bento MHL, Acamovic T, Makkar HPS (2005) The influence of tannin, pectin and polyethylene glycol on attachment of $15 \mathrm{~N}$-labelled rumen microorganisms to cellulose. Anim Feed Sci Technol 122(1-2):41-57

46. Jayanegara A, Togtokhbayar N, Makkar HPS, Becker K (2009) Tannins determined by various methods as predictors of methane production reduction potential of plants by an in vitro rumen fermentation system. Anim Feed Sci Technol 150:230-237

47. Krueger WK, Gutierrez-Bañuelos $H$, Carstens GE, Min BR, Pinchak WE, Gomez RR, Anderson RC, Krueger NA, Forbes TDA (2010) Effects of dietary tannin source on performance, feed efficiency, ruminal fermentation, and carcass and non-carcass traits in steers fed a high-grain diet. Anim Feed Sci Technol 159:1-9

48. Getachew G, Pittroff W, Putnam DH, Dandekar A, Goyal S, DePeters EJ (2008) The influence of addition of gallic acid, tannic acid, or quebracho tannins to alfalfa hay on in vitro rumen fermentation and microbial protein synthesis. Anim Feed Sci Technol 140:444-461

49. Leinmuller E, Menke KH (1990) Tannine in Futtermittenln fur Wiederkauer. 1. Chemische Eigenschaften und Reaktionen mit Makromolekulen. Ubersichten zur Tierernahrung 18:91-111

50. Wang CJ, Wang SP, Zhouc H (2009) Influences of flavomycin, ropadiar, and saponin on nutrient digestibility, rumen fermentation, and methane emission from sheep. Anim Feed Sci Technol 148:157-166

51. Hegarty RS (1999) Reducing rumen methane emissions through elimination of rumen protozoa. Aust J Agric Res 50:1321-1328

52. Wina E, Muetzel S, Hoffmann E, Makkar HPS, Becker K (2005) Saponins containing methanol extract of Sapindus rarak affect microbial fermentation, microbial activity and microbial community structure in vitro. Anim Feed Sci Technol 121:159-174

53. McMahon LR, McAllister TA, Berg BP, Majak W, Acharya SN, Popp JD, Coulman BE, Wang Y, Cheng KJ (2000) A review of the effects of forage condensed tannins on ruminal fermentation and bloat in grazing cattle. Can J Plant Sci 80:469-485

54. Sliwinski BJ, Kreuzer M, Wettstein HR, Machmuller A (2002) Rumen fermentation and nitrogen balance of lambs fed diets containing plant extracts rich in tannins and saponins and associated emissions of nitrogen and methane. Ach Anim Nutr 56:379-392

55. Leinmuller E, Steingass H, Menke KH (1991) Tannins in feeds for ruminants. II Effects on rumen metabolism in vitro. Ubersichten zur Tierernahrung 19:45-70

56. Hess HD, Kreuzer M, Diaz TE, Lascano CE, Carulla JE, Solvia CR (2003) Saponin rich tropical fruits affect fermentation and methanogenesis in faunated and defaunated fluid. Anim Feed Sci Technol 109:79-94

Publisher's Note Springer Nature remains neutral with regard to jurisdictional claims in published maps and institutional affiliations. 